\title{
EVALUATION OF SOME ALTERNATIVE CONTROL METHODS OF WASP BEETLE, Chlorophorus varius MULL. (COLEOPTERA: CERAMBYCIDAE) IN MANGO ORCHARDS IN EGYPT
}

\author{
Abd El-Moaty, R. M. ; S. M. Hashim and A. W. Tadros
}

Plant Protection Res. Inst., Agric. Res. Center, MOA, Giza, Egypt.

\begin{abstract}
Alternative control methods of Chlorophorus varius Mull. (Coleoptera: Cerambycidae) in mango orchards by horticultural, mechanical, microbial, and local chemical treatments were evaluated at El-Tall El-Kebeer, Ismailia Governorate during one and two successive years (2009/2010 and 2010/2011). The respective rates reductions of infestation with the following 12 treatments applied for single and two successive years were as follows: dormant pruning (31.04\% increased to $45.45 \%$ ), summer pruning (5.7 increased to $7.14 \%$ ), dormant and summer pruning (34.9 increased to $48.21 \%$ ), worming (4.19 increased to $6.85 \%$ ), bacterial or fungal (8.39 or 6.88 increased to 14.58 or $11.31 \%$ ), local painting or local spraying (73.32 or 72.15 increased to 84.52 or $79.46 \%)$, pruning, worming, together with bacterial or fungal (38.76 or 40.27 increased to 49.40 or $48.81 \%$ ), while pruning, worming, and local painting or local spraying treatments (84.23 or 82.55 increased to 95.24 or $93.75 \%$ ). Accordingly, it could be recommended that control of $C$. varius could be effectively achieved by the safe means such as winter pruning and local painting or spraying of the infested sites.
\end{abstract}

\section{INTRODUCTION}

In Egypt, mango orchards are seriously attacked with Chlorophorus varius Mull.(Coleoptera: Cerambycidae). Larvae bore deep tunnels inside the wood of the stem and branches, reducing the production, causing weakness and finally death of trees.

In spite of the high cost of chemical control, the adverse affect on the natural enemies (parasites, predators, and pathogens), and pollution of the environment, recommendations for the control of the fruit tree borers' infestation in mango orchards are still mainly directed towards the chemical control treatments.

Mango is a profitable crop, therefore plantations were progressively spread allover the new reclaimed lands in addition to old Delta lands. This study is a pioneer attempt to control the wasp beetle, $C$. varius, which is one of the mango production-limiting factors.

The available literature in Egypt included studies on the biology of $C$. varius on peach trees (Tadros, 1993), monitored the population fluctuation in mango orchards (Hashim, 2009) and fig (Kinawy et al., 1993), peach (Tadros, 1994), and apricot orchards (Tadros, et al.,2006) are essential in determination of the proper timing of the pest control treatments. Previous trials to control C. varius were applied in grapevine (El-Sherif and Tadros, 1985), peach (Helwa and Tadros, 2000), and plum (Tadros and Helwa, 2000) 
orchards. However, studies concerning the control of $C$. varius in mango orchards in Egypt and abroad are lacking and needs further exclusive work.

The aim of the present investigation was to prevent the mango yield losses through using non-traditional approaches for controlling $C$. varius to minimize the pesticide residues, reduce the outbreaks of secondary species, decrease the environmental pollution, magnify the role of the biological control agents and obtain better production of fruits.

\section{MATERIALS AND METHODS}

Experiments were carried out on mango orchard (10 feddans, 20 years old, different mixed varieties, not less than five meters length and $25-30 \mathrm{~cm}$ stem diameter ) highly infested with $C$. varius at El-Tall El-Kebeer, Ismailia Governorate. Trials were extended during two successive years from October 2009 to December 2011. The following 13 treatments were evaluated using completely randomized design (50 trees each treatment and each tree was considered a replicate).

a. Horticultural treatments:

1. Dormant pruning treatment: During December of each year (2009 2011), the regular horticultural winter pruning was carried out including the infested branches and stubs (characterized with exit holes).

2. Summer pruning treatment: During July(2009 - 2011), the newly infested branches were pruned.

3. Dormant and summer pruning treatments: Treatments numbers one and two were applied together.

b. Effect of mechanical treatment:

4. Worming treatment: Flexible wire was used to kill the larvae and pupae inside the tunnels through the infested wood of the stem and branches which appear after pruning .In the meantime the larval tunnels were exposed to its parasitoids and predators as well as the weather factors.

c. Microbiological treatments:

5. Bacterial treatment: Bactospeine F.C. (a.i. Bacillus thuringiensis (Berliner), 8500 International Units Ak / mg) at the rate of $200 \mathrm{cc} / 100$ liters of water was locally sprayed on the stem, main branches and pruning sites four times each season(2009 - 2011) (at monthly intervals on May, June, July and August) using knapsack sprayer.

6. Fungal treatment: Biofly F.C. (a.i., Beauveria bassiana, $3 \times 10^{7}$ spores / mg) at the rate of $400 \mathrm{cc} / 100 \mathrm{l}$. w. were locally sprayed on the stem, main branches and pruning sites four times each season(2009 - 2011) (at monthly intervals on May, June, July and August) using knapsack sprayer.

d. Local chemical treatments:

7. Local painting treatment: The MOA recommended Basudin (Diazinon) $60 \%$ EC and Cidial L (Phenthoate) $50 \%$ EC each at the rate of 300 $\mathrm{cc} / 100 \mathrm{I}$. w. was used to paint the stem, main branches and infested sites four times alternatively each season(2009 - 2011) at monthly intervals (May, June, July, and August). Painting was practical using a brush.

8. Local spraying treatment: The MOA recommended Basudin 
(Diazinon) $60 \%$ EC and Cidial L (Phenthoate) 50\% EC each at the rate of 300 $\mathrm{cc} / 100 \mathrm{I}$. w. was sprayed four times alternatively each season(2009-2011) at monthly intervals (May, June, July, and August). Spraying was practiced by a knapsack sprayer (20 liters capacity) and mainly directed towards the stem, branches and infested sites.

e. Combined treatments: $(2009-2011)$ :

9. Pruning, worming, and bacterial treatment: Treatment numbers 3,4 , and 5 were conducted together.

10. Pruning, worming, and fungal treatments: Treatments numbers 3,4 , and 6 were conducted together.

11. Pruning, worming, and local painting treatments: Treatments numbers 3,4 , and 7 were conducted together.

12. Pruning, worming, and local spraying treatments: Treatments numbers 3,4 , and 8 were carried out together.

f. Untreated:

13. Check treatment: Check trees were left untreated as control treatment.

g. Procedures of treatments: The previous 13 treatments were conducted during November 2009 to October 2010 season. During the $2^{\text {nd }}$ season (November 2010 to October 2011), the same previous treatments were repeated on other trees in another nearby area of the same orchard with the same technique for confirmation. In the meantime, the same previous 13 treatments were carried out on the same trees of the last year to evaluate the effect of the treatments when applied for two successive years (from November 2009 to October 2011).

Treatments were evaluated by counting the newly emerged beetles indicated by the newly exit holes on the trees during the following season. New exit holes were continuously counted and canceled by painting after each year treatment.

h. Evaluation of treatments: The efficiency of treatments was estimated according to the percentage reduction of the borer infestation (Henderson and Tilton, 1955), as follow:

$\%$ reduction of infestation $=[(\mathrm{C}-\mathrm{T}) / \mathrm{C}] 100$

Where, C: the mean number of new exit holes in untreated trees.

$\mathrm{T}$ : the mean number of new exit holes in treated trees.

Grouping of treatments was based on ANOVA test and "Least Significant Difference" (Snedecor and Cochran, 1990).

\section{RESULTS AND DISCUSSION}

Trials were conducted to evaluate the effect of different horticultural, mechanical, microbial, and local chemical treatments alone or in combination with each other's on the reduction of $C$. varius Mull. infestation in mango orchards. The direct effects of treatments were evaluated when applied for only one single year (2009-2010 or 2010-2011). The cumulative effects were also evaluated as well for two successive years (2009-2011). 
1.Effect of one single year treatments (Direct effect):

1.1. Effect of horticultural treatments:

1.1.1. Effect of dormant pruning treatment: As shown in (Table, 1), pruning treatment was of some considered value since the larvae feed and habitat inside the stem, main branches and stubs which rarely included in the dormant pruning. Thus, the reduction of infestation reached $26.6-35.03 \%$ (mean, 31.04\%).

1.1.2. Effect of summer pruning treatments: Due to the undetectable symptoms of new infestation and the borer infestation did not occur in the smaller branches, summer pruning was of some value in reducing the borer infestation, showing 3.19-7.96\% (mean, 5.7\%) (Table, 1).

1.1.3. Effect of dormant and summer pruning treatments: The reduction in $C$. varius infestation increased when applying dormant and summer treatments together compared with each treatment alone (Table, 1), they were valuable and ranged $30.14-39.17 \%$ (mean, 34.9\%).

\subsection{Effect of mechanical treatment:}

1.2.1. Effect of worming treatment: Worming treatment was not effective owing to the deep larval habitat inside the mango wood. However, this treatment exposed the larval tunnels to parasites and predators as well as the weather factors to do their effective role in the reduction of infestation. The reduction of infestation reached $3.55-4.78 \%$ (mean, $4.19 \%$ ) (Table, 1).

\subsection{Effect of microbial treatments:}

1.3.1. Effect of bacterial treatment: Bacterial treatment was relatively inactive in the field as the bacteria highly affected with the weather factors (especially higher temperature and hot wind) and the difficulty of these bacteria to reach the larvae inside their tunnels. Therefore, this treatment was less effective as the percentage reduction of infestation recorded only 8.168.60\% (mean, 8.39\%) (Table, 1).

1.3.2. Effect of fungal treatment: As in bacteria, the percentage reduction in C. varius infestation due to fungal treatment was as low as $6.37-7.45 \%$ (mean, 6.88\%) (Table, 1).

1.4. Effect of local chemical treatments:

1.4.1. Effect of local painting treatment: Local painting four times / year with recommended insecticides on the stem and larger pruned areas significantly increased the percentage reduction of $C$. varius infestation showing 72.34-74.20\% (mean, 73.32\%) (Table, 1). This high percent reduction was due to the unsuccessful trails of the borer to infest these sites.

1.4.2. Effect of local spraying treatment: Local spraying four times / year with recommended insecticides to the stem, bases of main branches and pruned stubs adequately reduced $C$. varius infestation with $69.75-74.82 \%$ (mean, $72.15 \%$ ) as shown in Table (1). This treatment hindered the beetle settings, the beetle oviposition, hatching and larval entry inside the mango wood. 
Table 1: Effect of single year treatment on the percentage reduction of C. varius Mull. infestation in mango orchards at Ismailia Governorate during 2009-2010 and 2010-2011 seasons.

\begin{tabular}{|c|c|c|c|c|c|c|}
\hline \multirow[b]{3}{*}{ Treatments } & \multicolumn{6}{|c|}{$\%$ reduction of infestation } \\
\hline & \multicolumn{2}{|c|}{$\begin{array}{c}1^{\text {st }} \text { year } \\
2009-2010\end{array}$} & \multicolumn{2}{|c|}{$\begin{array}{c}2^{\text {nd }} \text { year } \\
2010-2011\end{array}$} & \multicolumn{2}{|c|}{ Mean } \\
\hline & \begin{tabular}{|c|} 
Mean no. \\
of exit \\
holes
\end{tabular} & $\%$ & $\begin{array}{l}\text { Mean no. } \\
\text { of exit } \\
\text { holes }\end{array}$ & $\%$ & $\begin{array}{l}\text { Mean } \\
\text { no. of } \\
\text { exit } \\
\text { holes }\end{array}$ & $\%$ \\
\hline $\begin{array}{l}\text { Horticultural Treatments: } \\
\text { (1)Dormant pruning } \\
\text { (2)Summer pruning } \\
\text { (3)Dormant \& summer pruning }\end{array}$ & $\begin{array}{l}20.4 \\
28.9 \\
19.1\end{array}$ & $\begin{array}{c}35.03 \\
7.96 \\
39.17\end{array}$ & $\begin{array}{l}20.7 \\
27.3 \\
19.7\end{array}$ & $\begin{array}{c}26.60 \\
3.19 \\
30.14\end{array}$ & $\begin{array}{l}20.55 \\
28.1 \\
19.4\end{array}$ & $\begin{array}{c}31.04 \\
5.7 \\
34.9\end{array}$ \\
\hline $\begin{array}{l}\text { Mechanical Treatments: } \\
\text { (4)Worming }\end{array}$ & 29.9 & 4.78 & 27.2 & 3.55 & 28.55 & 4.19 \\
\hline $\begin{array}{l}\text { Microbial Treatments: } \\
\text { (5)Bacterial } \\
\text { (6)Fungal }\end{array}$ & $\begin{array}{l}28.7 \\
29.4 \\
\end{array}$ & $\begin{array}{l}8.60 \\
6.37 \\
\end{array}$ & $\begin{array}{l}25.9 \\
26.1\end{array}$ & $\begin{array}{l}8.16 \\
7.45 \\
\end{array}$ & $\begin{array}{c}27.3 \\
27.75 \\
\end{array}$ & $\begin{array}{l}8.39 \\
6.88 \\
\end{array}$ \\
\hline $\begin{array}{l}\text { Local Chemical Treatments: } \\
\text { (7)Local painting } \\
\text { (8)Local spraying }\end{array}$ & $\begin{array}{l}8.1 \\
9.5\end{array}$ & $\begin{array}{l}74.20 \\
69.75\end{array}$ & $\begin{array}{l}7.8 \\
7.1\end{array}$ & $\begin{array}{l}72.34 \\
74.82\end{array}$ & $\begin{array}{l}7.95 \\
8.3\end{array}$ & $\begin{array}{l}73.32 \\
72.15\end{array}$ \\
\hline $\begin{array}{l}\text { Combined Treatments: } \\
\text { Treatments, } 3+4+5 \\
\text { Treatments, } 3+4+6 \\
\text { Treatments, } 3+4+7 \\
\text { Treatments, } 3+4+8\end{array}$ & $\begin{array}{l}17.8 \\
17.1 \\
5.3 \\
5.9\end{array}$ & $\begin{array}{l}43.31 \\
45.54 \\
83.12 \\
81.21\end{array}$ & $\begin{array}{l}18.7 \\
18.5 \\
4.1 \\
4.5\end{array}$ & $\begin{array}{l}33.69 \\
34.40 \\
85.46 \\
84.04\end{array}$ & $\begin{array}{c}18.25 \\
17.8 \\
4.7 \\
5.2\end{array}$ & $\begin{array}{l}38.76 \\
40.27 \\
84.23 \\
82.55\end{array}$ \\
\hline $\begin{array}{l}\text { Untreated Treatments: } \\
\text { Check }\end{array}$ & 31.4 & -- & 28.2 & -- & 29.8 & -- \\
\hline
\end{tabular}

1.5. Effect of combined treatments:

1.5.1. Effect of pruning, worming, and bacterial treatments: Table (1) indicated that bacterial treatment did not increase the effectiveness of the combined treatments as the percentage reduction in $C$. varius reached 33.69$43.31 \%$ (mean, $38.76 \%$ ). The obtained results are mainly due to pruning and worming treatments.

1.5.2 Effect of pruning, worming, and fungal treatments: As mentioned above, the effectiveness of these treatments was mainly due to pruning and worming but the fungal treatment did not add noticeable effect. This combined treatment resulted in $34.40-45.54 \%$ (mean, 40.27\%) (Table, 1).

1.5.3. Effect of pruning, worming, and local painting treatments: Excellent results were obtained when these combined treatments were applied together showing 83.12-85.46\% (mean, 84.23\%) reductions of infestation (Table, 1). The effect was due to all combined treatments.

1.5.4. Effect of pruning, worming, and local spraying treatments: As shown in Table (1), almost equal excellent and satisfactory results were achieved when these combined treatments were applied together showing $81.21-84.04 \%$ (mean, $82.55 \%$ ) reductions in infestation.

2.Effect of two successive year treatments (Cumulative effect):

2.1. Effect of horticultural treatments alone: Data in Table (2) indicated that, dormant pruning treatment alone in winter somewhat reduced $C$. varius infestation in mango orchards when applied for two successive years. This 
relatively low percentage reduction of infestation (45.45\%) was due to that, the larval infestation was mainly concentrated in the stem and main branches. However, winter pruning somewhat shared in reducing the borer infestation. Summer pruning had slight effect $(7.14 \%)$ in this respect, although it was repeated for two successive years. Summer pruning did not share in the reduction of infestation and should be excluded in the integrated control program. Dormant and summer pruning treatments together for two successive years reduced infestation with $48.21 \%$.

2.2. Effect of mechanical treatment alone: Worming treatment (killing larvae, pre-pupae, and pupae stages) was generally difficult to apply but it had a slight effect in the reduction of infestation (6.85\%) (Table, 2$)$.

Table 2: Effect of two successive year treatments on the percentage of reduction in $C$. varius Mul. infestation in mango orchards at Ismailia Governorate during the two successive seasons (2009-2011) and differences between one and two year's treatments.

\begin{tabular}{|c|c|c|c|c|}
\hline \multirow[b]{2}{*}{ Treatments } & \multicolumn{2}{|c|}{ Two successive years } & \multirow{2}{*}{$\begin{array}{c}\begin{array}{c}\text { single } \\
\text { year }\end{array} \\
\% \text { reduction } \\
\text { of infestation }\end{array}$} & \multirow[b]{2}{*}{$\begin{array}{l}\text { Differences } \\
\text { between } 1 \& \\
2 \text { years }\end{array}$} \\
\hline & $\begin{array}{l}\text { Mean } \\
\text { no. of } \\
\text { exit } \\
\text { holes }\end{array}$ & $\begin{array}{l}\% \text { reduction } \\
\text { of infestation }\end{array}$ & & \\
\hline $\begin{array}{l}\text { Horticultural Treatments: } \\
\text { (1)Dormant pruning } \\
\text { (2)Summer pruning } \\
\text { (3)Dormant \& summer pruning }\end{array}$ & $\begin{array}{l}18.3 \\
31.2 \\
17.4\end{array}$ & $\begin{array}{c}45.45 \\
7.14 \\
48.21\end{array}$ & $\begin{array}{c}31.04 \\
5.7 \\
34.9\end{array}$ & $\begin{array}{c}14.4 \\
1.4 \\
13.3\end{array}$ \\
\hline $\begin{array}{l}\text { Mechanical Treatments: } \\
\text { (4)Worming }\end{array}$ & 31.3 & 6.85 & 4.19 & 2.7 \\
\hline $\begin{array}{l}\text { Microbial Treatments: } \\
\text { (5)Bacterial } \\
\text { (6)Fungal }\end{array}$ & $\begin{array}{l}28.7 \\
29.8\end{array}$ & $\begin{array}{l}14.58 \\
11.31\end{array}$ & $\begin{array}{l}8.39 \\
6.88\end{array}$ & $\begin{array}{l}6.2 \\
4.4\end{array}$ \\
\hline $\begin{array}{l}\text { Local Chemical Treatments: } \\
\text { (7)Local painting } \\
\text { (8)Local spraying }\end{array}$ & $\begin{array}{l}5.2 \\
6.9 \\
\end{array}$ & $\begin{array}{l}84.52 \\
79.46 \\
\end{array}$ & $\begin{array}{l}73.32 \\
72.15 \\
\end{array}$ & $\begin{array}{l}11.2 \\
7.3 \\
\end{array}$ \\
\hline $\begin{array}{l}\text { Combined Treatments: } \\
\text { Treatments, } 3+4+5 \\
\text { Treatments, } 3+4+6 \\
\text { Treatments, } 3+4+7 \\
\text { Treatments, } 3+4+8\end{array}$ & $\begin{array}{l}17.0 \\
17.2 \\
1.6 \\
2.1\end{array}$ & $\begin{array}{l}49.40 \\
48.81 \\
95.24 \\
93.75\end{array}$ & $\begin{array}{l}38.76 \\
40.27 \\
84.23 \\
82.55\end{array}$ & $\begin{array}{c}10.6 \\
8.5 \\
11 \\
11.2\end{array}$ \\
\hline $\begin{array}{l}\text { Untreated Treatments: } \\
\text { Check }\end{array}$ & 33.6 & ---- & ---- & \\
\hline
\end{tabular}

2.3. Effect of microbial treatments: The pathogenic bacteria or fungus was relatively useless even when applied cumulatively for two successive years (14.58 and $11.31 \%$, respectively) (Table, 2).

2.4. Effect of local chemical treatments: Local painting and local spraying 4 times / year was quite effective in the reduction of $C$. varius infestation especially when was applied for two successive years (84.52 and $79.46 \%$, respectively) (Table, 2). 


\subsection{Effect of combined treatments:}

Applying dormant pruning, summer pruning, worming, microbial, and/or local chemical treatments in different combinations resulted in adequate reduction in $C$. varius infestation in mango orchards especially when carried out yearly.

Winter and summer pruning, worming and bacterial treatments showed $49.40 \%$ reduction of infestation when conducted for two successive years (Table, 2). Applying winter and summer pruning, worming and fungal treatments for two successive years resulted in almost similar results (48.81\%). Winter and summer pruning, worming with local painting for two successive years almost doubled percentage reduction in the borer infestation (95.24\%). Winter and summer pruning, worming with local spraying for two successive years resulted in almost similar percentage reduction in the borer infestation (93.75\%).

Statistical analysis: Statistical analysis and grouping of the 13 treatments applied for one and two years concluded that there were significant differences between treatments classified as: \{insignificant differences between the same letters of grouping\}

1. Superior group $(\mathbf{7 5}-\mathbf{1 0 0} \%)$ : approved by the MOA Committee

1. Pruning, worming, and local painting for two years (95.24\%) A

2. Pruning, worming, and local spraying for two years $(93.75 \%) \mathrm{A}$

3. Local painting for two years (84.52\%) A

4. Pruning, worming, and local painting for one year (84.23\%) A

4. Pruning, worming, and local spraying for one year $(82.55 \%) \mathrm{A}$

5. Local spraying for two years $(79.46 \%) \mathrm{A}$

2. Sufficient group (50 - less than $\mathbf{8 0} \%$ ):

1. Local painting for one year $(73.32 \%) \mathrm{A}$

2. Local spraying for one year $(72.15 \%)$ A

3. Moderate group ( 30 - less than $\mathbf{5 0 \%}$ ):

1. Pruning + Worming + Bacterial for two years $(49.40 \%) B$

2. Pruning + Worming + Fungal for two years $(48.81 \%) B$

3 . Dormant and summer pruning for two years $(48.21 \%) \mathrm{B}$

4. Dormant pruning for two years $(45.45 \%)$ BC

5. Pruning + Worming + Bacterial for one year $(40.27 \%) B$

6. Pruning + Worming + Fungal for one year $(38.76 \%) \mathrm{B}$

7. Dormant and summer pruning for one year $(34.9 \%) \mathrm{BC}$

8. Dormant pruning for one year (31.04\%) BC

4. Least group (less than $30 \%$ ):

1. Bacterial for two years (14.58\%) D

2. Fungal for two years $(11.31 \%) \mathrm{D}$

3. Bacterial for one year $(8.39 \%) \mathrm{D}$

4. Fungal for one year $(6.88 \%) \mathrm{D}$

5. Worming for two years $(6.85 \%) \mathrm{BC}$

6. Summer pruning for two years $(7.14 \%) \mathrm{CD}$

7. Summer pruning for one year $(5.7 \%) \mathrm{CD}$

8. Worming for one year $(4.19 \%) \mathrm{C}$ 
Abd El-Moaty, R. M. et al.

From the foregoing results, it could be concluded that the direct effect of one single year treatments on $C$. varius infestation varied from one treatment to another. The cumulative effect of two successive year treatments proved that the infestation could be highly reduced if these treatments repeated yearly. The effect of horticultural treatments alone (winter and summer pruning) reached 34.9 and $48.21 \%$ reduction of infestation when applied for 1 and 2 years, respectively. However, the majority of the effect was due to dormant winter pruning (31.04 and $45.45 \%$, respectively). Summer pruning was negligible (5.7 and $7.14 \%$, respectively). The direct effect of mechanical treatment alone (worming) was of low value $(4.19 \%)$. The cumulative effect for two successive years was slightly increased to reach $6.85 \%$.

Microbial treatments with bacteria or fungus showed very low effects (8.39 and $6.88 \%$ ) for one year slightly increased to 14.58 and $11.31 \%$ for two years. This was owing to the phenomenon that the pest hide inside the tree wood under the bark in addition that the bacteria and fungus were highly affected with the weather factors in the field and failed to reach the larvae inside.

Local painting and local spraying were quite effective in the reduction of the borers' infestation (73.32 and $72.15 \%)$. The cumulative effect for two years increased the reduction of infestation to 84.52 and $79.46 \%$, respectively.

Applying dormant pruning in winter with the summer pruning, worming together with pathogenic microbial or local chemical treatments in different combinations magnified the reduction of infestation and greatly increased the reduction of infestation when applied for two successive years. Pruning, worming and bacterial or fungal treatments reduced the infestation with about 40.27 or $38.76 \%$ for one year and 49.40 or $48.81 \%$ for two years. However, local painting or local spraying with pruning, and worming treatments greatly reduced the infestation with 84.23 or $82.55 \%$ for one year and 95.24 or $93.75 \%$ for two years, respectively.

Repeating winter and summer pruning together increased the reduction of infestation with $13.3 \%$, (winter pruning only increased with $14.4 \%$ while summer pruning only increased with $1.4 \%$ ). Repeating worming treatment increased the reduction of infestation with $2.7 \%$. Repeating bacterial or fungal treatments increased the reduction of infestation with $4.4-6.2 \%$. Repeating local spraying or painting treatments increased the reduction of infestation with $7.3-11.2 \%$, respectively. Repeating the different combinations of pruning and worming with microbial treatments increased the reduction of infestation with $8.5-10.6 \%$ but with local chemical treatments it increased with $11 \%$.

It could be concluded that the low cost and environmentally safe treatments such as winter pruning increased the reduction of infestation and was of great value, and should be repeated each year. Repeating local spraying or painting treatments was also valuable, especially when applied after harvesting. Microbial and mechanical treatments should be excluded although they are environmentally safe. 
The obtained results are somewhat in agreement with Helwa and Tadros (2000) and Tadros and Helwa (2000) who studied the effect of horticultural, mechanical, and local chemical treatments on $C$. varius infestation and yield production in peach and plum orchards, respectively. They recommended dormant pruning in winter, worming, local chemical treatments, and combined treatments as effective and environmentally safe means of control.

\section{REFERENCES}

El-Sherif, S.I. and A.W. Tadros (1985); Screening of certain insecticides for the control of the wasp beetle, Chlorophorus varius Mull. (Coleoptera: Cerambycidae) on grapevine. Bull. Fac. Agric., Univ. of Cairo, Egypt, 36 (1): 601-608.

Hashim, S. M. (2009): Ecological and Control Studies on Mango Tree Borers and Their Natural Enemies in Egypt. Ph D Thesis, Faculty of Science, Cairo University.

Helwa, A.Y.H. and A.W. Tadros (2000): Effect of horticultural, mechanical and local chemical treatments on Chlorophorus varius infestation and yield production in peach orchards. J. Agric. Sci., Mansoura Univ., 25 (8): 374-385.

Henderson, C.F. and E.W. Tilton (1955): Test with acaricides against the brown wheat mite. J. Econ. Entomol., 48: 157-161.

Kinawy, M.M.; F.F. Abd-Allah and A.W. Tadros (1993): Emergence of adults of Chlorophorus varius and its relation to climatic conditions in fig orchards. Communications in Science \& Development Res., Alexandria, Egypt. 42 (644): 55-65.

Snedecor, W and A. Cochran (1990): Statistical Methods. The lowa State Univ. press, Ames, lowa, USA.

Tadros, A.W. (1993): The life-cycle of the wasp beetle, Chlorophorus varius Mull. (Coleoptera: Cerambycidae) on peach in Egypt. Egypt. J. Agric. Res., Cairo, Egypt, 71 (2): 429 - 435. \{Presented to the "4 $4^{\text {th }}$ Professional Fruit Worker Conference", Ashville, North Carolina, U. S. America, Oct. 1989, 4 (15)\}.

Tadros, A.W. (1994): Monitoring the population of the wasp beetle, Chlorophorus varius Mull. (Coleoptera: Cerambycidae) on peach and its hosts in Egypt. Egypt. J. Agric. Res., 72 (1): 103-115. $\left\{5^{\text {th }}\right.$ Professional Fruit Workers Conf., Ashville, North Carolina, USA, Oct. 17-18, 1990, $5(16)\}$.

Tadros, A.W., A. M. Abdel-Rahman and I. A. Abdel-Hamid (2006): Stone Fruit Tree Pests: (5) Monitoring the major apricot tree borers (Ptosima undecimmaculata, Chlorophorus varius, Macrotoma palmata, and Scolytus amygdali) in Egypt. Egypt. J. Agric. Res., Egypt.

Tadros, A.W. and A.Y.H. Helwa, (2000): Effect of horticultural, mechanical, and local chemical treatments on Chlorophorus varius infestation and yield production in plum orchards. $7^{\text {th }}$ Arab Conf. of Plant Protection, Amman, Jordan, 16-22 Oct., 2000. 


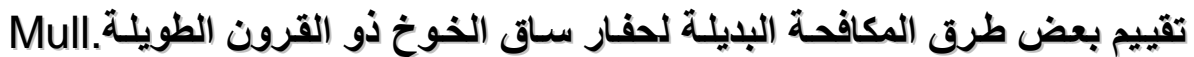
Chlorophorus varius

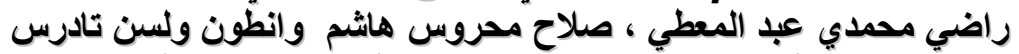
معهد بحوث وقيّة النباتات ـ مركز البحوث الزراعية ـ وزارة الزراعة ـ الدقي - الجيزة مصر.

تم تقييم فعالية بعض الطرق البديلة لكافحسة حفار ساق الخوخ ذو القرون الطويلـة Chlorophorus varius

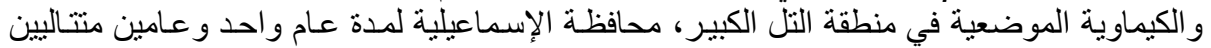

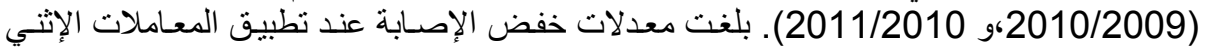

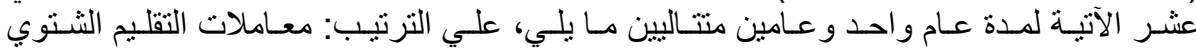

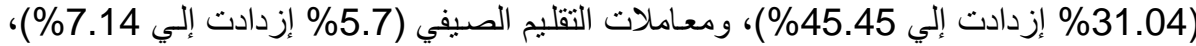

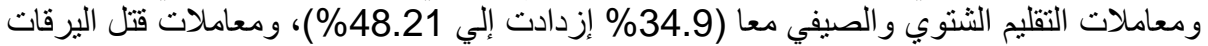

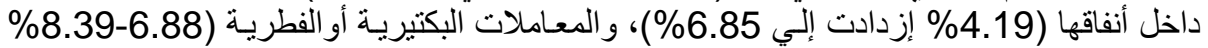

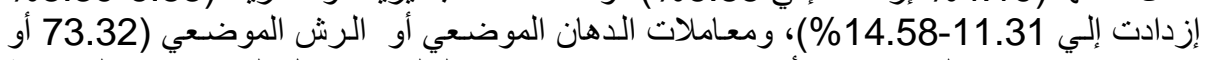

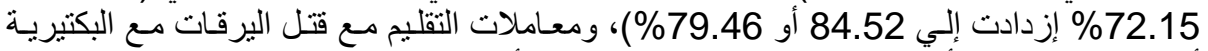

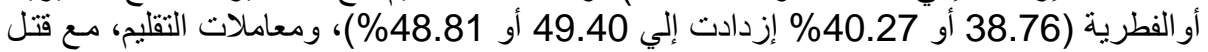

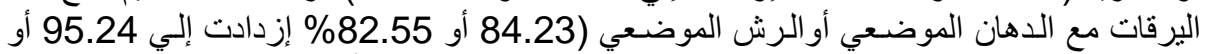

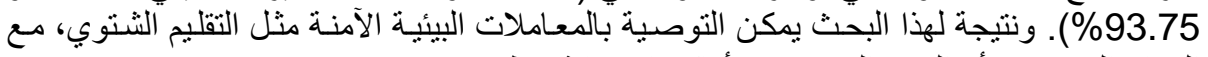
الدهان الموضعي أو الرش الموضعي لأماكن الإصابة فقط.

كلية الزراعة - جامعة المنصورة مركز البحوث الزراعية
قام بتحكيم البحث

أ.د / عبد البديع عبد الحميد غانم أ.د / سعيد محمد حجاج عيد البعيد 